\title{
Kinetics and equilibrium study of chromium adsorption on zeoliteNaX
}

\author{
P. K. Pandey; *S. K. Sharma; S. S. Sambi
}

University School of Chemical Technology, Guru Gobind Singh Indraprashtha University, Delhi-110403, India

\author{
Received 28 October 2009; $\quad$ revised 17 January 2010; $\quad$ accepted 16 February 2010
}

\begin{abstract}
This study aims to report Batch adsorption study of hexavalent chromium, Cr (VI) on zeoliteNaX. Kinetics of Cr (VI) adsorption and adsorption isotherms were determined by varying operating parameters such as $\mathrm{pH}$, initial concentration, temperature and contact time. ZeoliteNaX was found to remove Cr (VI) in acidic solutions down to ppm level at $\mathrm{pH}$ of about 4. Removal rate of Cr (VI) was found to decrease as pH rises above 4.0. Langmuir, Freundlich, Temkin and Redlich-Peterson models were applied to adsorption equilibrium data to find the best amongst these models. Langmuir model with $\mathrm{R}^{2}=0.9711$ best fits the adsorption data. The kinetics of adsorption was found to follow the first order reversible reaction. The separation parameter, $\mathrm{R}_{\mathrm{L}}$ values of less than 1.0 i.e., $0.7369,0.5834$ and 0.4828 corresponding to initial concentrations of 10,20 and $30 \mathrm{mg} / \mathrm{L}$, respectively indicated that adsorption of $\mathrm{Cr}$ (VI) on zeoliteNaX is favoured. The estimated values of thermodynamic parameters such as heat of adsorption and standard gibbs free energy confirmed the exothermic nature of adsorption of Cr (VI) on zeoliteNaX.
\end{abstract}

Keywords: Diffusion; First order reversible reaction; Isotherm; Mass transfer; Regeneration; Thermodynamics

\section{INTRODUCTION}

Metals and their derivatives are potential pollutants that could be particularly problematic due to their stability and mobility. Hexavalent Chromium, Cr (VI) is reported to be a powerful carcinogen capable of modifying the deoxyribonucleic acid (DNA) transcription process in both animals and humans that may result in important chromosome aberrations. It is, therefore, essential to remove Cr (VI) from wastewaters of electroplating, dye, cement, leather tanning and paint industries which may contain up to hundreds of $\mathrm{mg} / \mathrm{L}$ of chromium though the tolerance limit of $\mathrm{Cr}$ (VI) for discharge into inland surface waters is only $0.1 \mathrm{mg} / \mathrm{L}$ and in potable water it is as low as $0.05 \mathrm{mg} / \mathrm{L}$ (Kobya, 2004). Several conventional techniques, including adsorption, electro-chemical precipitation, reverse osmosis, etc. are used for treatment of effluents containing metal ions. For one reason or the other, most of these techniques are not suitable for large-scale wastewater treatment, especially in developing countries (Gupta and Babu, 2006). Hexavalent chromium exists mainly as $\mathrm{H}_{2} \mathrm{CrO}_{4}, \mathrm{HCrO}_{4}^{-}, \mathrm{Cr}_{2} \mathrm{O}_{7}^{2-}$ and $\mathrm{CrO}_{4}^{2-}$ in aqueous environment and can not precipitate out by treatment with carbonate or hydroxide (Sun et

《*Corresponding Author Email: skschem@sify.com

Tel.: +11 2390 0240; Fax: +11 23900169 $a l .$, 2007). Adsorption is versatile and effective method for removing chromium particularly when it is combined with appropriate regeneration step. This reduces the problem of sludge disposal and renders the system economically viable, especially when the adsorbents used are also of low cost. Adsorption process is used in a variety of important industrial applications and now it is increasingly used on large scale as an economical and efficient separation technique for metal ion removal from wastewater (Zvinowanda et al., 2009). A number of researchers have studied the removal of heavy metal ions from aqueous solution using different adsorbents like granular activated carbon (Agarwal et al., 1999), soya cake (Daneshvar et al., 2002), rubber tyre and sawdust (Hamadi et al., 2001), activated sludge (Xie and Kang, 2003), fly ash (Meng and Dermatas, 2003), wheat bran (Nameni et al., 2008), natural sorbent materials (Shah et al., 2009) and rice husk based activated carbon (Guo et al., 2003). Easily available activated carbon prepared by pyrolysis of wood / agricultural waste is generally used as an adsorbent in most of the commercial scale treatment units. The activated carbon is used only once and regeneration is not possible when metal ions are removed. In the treatment of industrial effluents containing metal ions, 
chelating agents are also used to enhance the process performance, though at an additional cost of chelating agent. If one has to avoid the use of chelating agents, alternative adsorbents have to be identified. This has prompted many researchers to look for different low cost adsorbents through their experimental studies.

Various kinds of soils and clay materials have been tried by several investigators (Okada et al., 2005). Retention of heavy metal cations in soils is due to their strong adsorption onto the negatively charged soil surfaces, their ability to form complex molecules with organics found in the soil and the formation of oxides, hydroxides and other insoluble minerals in soil (Stewart et al., 2003). Several types of crystalline clay minerals such as zeolites are also suitable due to their easy availability globally (Mark, 1998; Mier et al., 2001; Inglezakis, 2004; Meshko et al., 2006) for the removal of heavy metal cations. The metal adsorption efficiency of such clays is due to their chemical and mechanical stability, high surface area, permanent negative charge and a variety of surface and structural properties (Krishna et al., 2000). Fendorf(1994) concluded from experimental studies that $\mathrm{Cr}$ (VI) is appreciably retained in soil colloids having net positive charge due to its anionic nature. $\mathrm{Cr}$ (VI) is adsorbed by a variety of soil phases with hydroxyl groups on their surfaces such as those present in kaolinite and montmorillonite (Bradl, 2004). Khan et al. (1995) have reported that hydroxylated surfaces of oxides of $\mathrm{Al}, \mathrm{Ca}, \mathrm{Mg}, \mathrm{Si}$, etc. acquire charge when present in aqueous solution through amphoteric dissociation.

Since zeoliteNaX contain oxides of aluminium and silicon, its surface should adsorb Cr (VI) as it may also acquire positive charge in acidic medium. Most of the literature available on adsorption of metal ions by zeolites is for the removal of cations and there is hardly any reference available on the removal of anions like $\mathrm{Cr}$ (VI). Hence, study on the application of zeoliteNaX for the removal of Cr (VI) from wastewater as an alternative low cost adsorbent is important. In this study, the possibility of using zeoliteNaX to remove $\mathrm{Cr}$ (VI) from aqueous solution is investigated. The effect of various parameters such as contact time, initial $\mathrm{pH}$, temperature and initial concentration of $\mathrm{Cr}(\mathrm{VI})$ on the removal efficiency of zeoliteNaX was studied. The adsorption data were analyzed using various equilibrium adsorption models, kinetic models, mass transfer and thermodynamic models. The research work was carried out from January 2008 to April 2009 at
University School of Chemical Technology, Guru Gobind Singh Indraprastha University, Delhi 110403, India.

\section{MATERIALS AND METHODS}

\section{Chemicals}

The stock solution of chromium with concentration of $500 \mathrm{mg} / \mathrm{L}$ was prepared by dissolving $1.414 \mathrm{~g}$ of $\mathrm{K}_{2} \mathrm{Cr}_{2} \mathrm{O}_{7}$ in $1000 \mathrm{~mL}$ deionised water in volumetric flask. This solution was then diluted to obtain standard solutions containing 10, 15, 20, 25, 30, 40 and $50 \mathrm{mg} / \mathrm{L}$ of Cr (VI). Hydrochloric acid and/or sodium hydroxide solutions were used throughout experiments to adjust $\mathrm{pH}$ of the solution.

\section{Adsorbent}

Particles of zeoliteNaX represented by chemical formula $\mathrm{Na}_{81}\left(\mathrm{AlO}_{2}\right)_{81}\left(\mathrm{SiO}_{2}\right)_{111}$ having cylindrical shape with size of $1.5 \mathrm{~mm}$ and bulk density $600 \mathrm{~g} / \mathrm{L}$, purchased from Central Drug House (C.D.H.), India were used as the adsorbent in this study. The adsorbent is contacted with $1 \mathrm{M} \mathrm{NaCl}$ solution to convert it into a near homoionic state in Na form (Curkovic et al., 1997) followed by washing with deionised water and drying in oven at $373 \mathrm{~K}$. The dried adsorbent was stored in desiccator. All the chemicals and the adsorbent used were of LR grade and obtained from C.D.H., India.

\section{Analysis}

Chromium concentration in different solutions was determined using atomic absorption spectrophotometer model AAS 4141, ECIL, India at wave length $357.9 \mathrm{~nm}$ in flame mode using air-acetylene flame. The pH meter, model PHEP, Hanna instrument, Italy,was used in this study between $\mathrm{pH}$ range 4-7.

\section{Equilibrium study}

The equilibrium study was carried out by varying parameters such as initial Cr (VI) ion concentration, $\mathrm{pH}$ and temperature. $250 \mathrm{~mL}$ solution of $\mathrm{Cr}(\mathrm{VI})$ was taken in $500 \mathrm{~mL}$ conical flask and the initial $\mathrm{pH}$ was adjusted using $\mathrm{HCl} / \mathrm{NaOH}$. One gram of zeoliteNaX was added and flask was kept in the shaking incubator model DKS1020, Daiki, Korea at desired temperature for $24 \mathrm{~h}$. Flask was kept sealed in order to minimize losses to atmosphere. After $24 \mathrm{~h}$, the solution was analyzed for $\mathrm{Cr}$ (VI) concentration. The amount of $\mathrm{Cr}$ (VI) adsorbed on the adsorbent $(Q)$ was calculated by material balance of chromium concentration in solution using Eq. (1). 


$$
Q=\frac{\left(C_{A o}-C_{A}\right) V}{W}
$$

Where, $C_{A o}$ and $C_{A}$ are the Cr (VI) concentration $(\mathrm{mg} / \mathrm{L})$ in solution initially and at any time $(t) . V$ is volume taken in flask and $\mathrm{W}$ is weight of adsorbent used. At equilibrium state, $C_{A}=C_{A e}$ and $Q=Q_{e}$.

The initial concentration of $\mathrm{Cr}(\mathrm{VI})$ was varied from 5 to $50 \mathrm{mg} / \mathrm{L}$. The temperature was varied from $292 \mathrm{~K}$ to $308 \mathrm{~K}$ and the initial $\mathrm{pH}$ was varied from 4.0 to 7.0. Percentage removal was calculated using Eq. 2. Correction for any adsorption of chromium on the conical flask surface was made using the control experiments carried out in the absence of zeoliteNaX. These experiments indicated no detectable adsorption by the conical flask surface.

$\operatorname{Cr}(\operatorname{VI}) \operatorname{removal}(\%)=\frac{100\left(C_{A o}-C_{A}\right)}{C_{A o}}$

\section{Kinetics study}

Kinetics study was conducted by varying initial concentration of Cr (VI). Here, $250 \mathrm{~mL}$ solution of Cr (VI) was taken into $500 \mathrm{~mL}$ conical flask placed in thermostatically controlled water bath placed on a magnetic stirrer. When pre-determined temperature was attained, $1.0 \mathrm{gm}$ of zeoliteNaX was added to the flask. During the experiment, small samples of the solution were taken out for analysis at predetermined intervals of $2 \mathrm{~h}$ because contact time to attain equilibrium with the zeoliteNaX is experimentally found to be about 4560 min. Concentration of $\mathrm{Cr}$ (VI) on the adsorbent was obtained by material balance. The initial concentration of $\mathrm{Cr}$ (VI) ion was varied from 5 to $50 \mathrm{mg} / \mathrm{L}$. During the experiment temperature was controlled at $293+1 \mathrm{~K}$ and

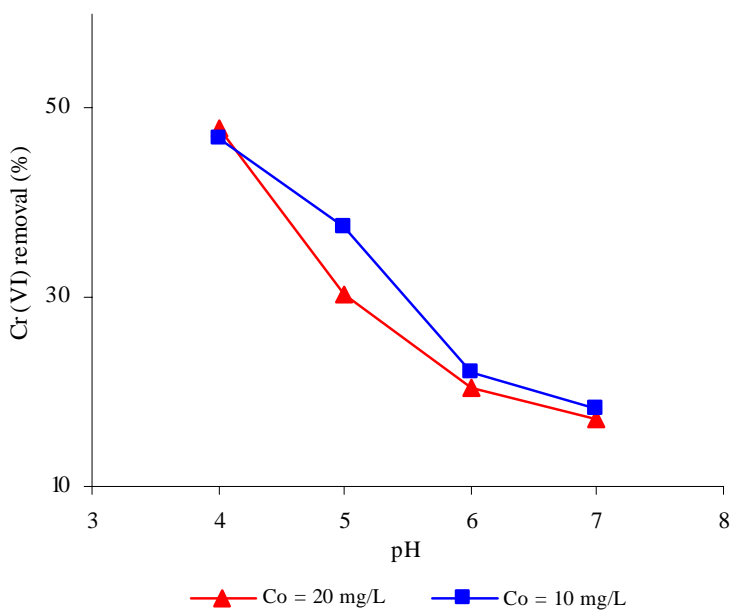

Fig. 1: Effect of $\mathrm{pH}$ on $\mathrm{Cr}(\mathrm{VI})$ removal initial $\mathrm{pH}$ was adjusted to the optimum value of 4.0 . The percentage removal was calculated using Eq. 2.

\section{Regeneration study}

One gram of adsorbent used in the equilibrium study was regenerated for $2 \mathrm{~h}$ at atmospheric conditions by contacting it with $250 \mathrm{~mL}$ of $1 \mathrm{M} \mathrm{NaCl}$ solution contained in $500 \mathrm{~mL}$ conical flask. This was repeated three times with fresh solution. Finally, the adsorbent was washed with deionised water to remove all the free chloride ions so that the wash water passed the silver nitrate test. This regeneration step was repeated three time to check the effect of regeneration on the uptake capacity of the adsorbent.

\section{RESULTS AND DISCUSSION}

\section{Effect of $p H$}

The $\mathrm{pH}$ is an important parameter that affects the adsorption behavior of metal ions in aqueous systems. Percentage removal of $\mathrm{Cr}$ (VI) vs. $\mathrm{pH}$ is shown in Fig. 1 for contact time of $24 \mathrm{~h}$, at $293 \pm 1 \mathrm{~K}$ and two initial concentrations of 10 and $20 \mathrm{mg} / \mathrm{L}$. At initial concentration of $20 \mathrm{mg} / \mathrm{L}$, the removal of $\mathrm{Cr}$ (VI) decreases from $48 \%$ to $17 \%$ as $\mathrm{pH}$ increases from 4.0 to 7.0. Similar trend for $\mathrm{Cr}$ (VI) adsorption on activated carbon is reported by Mohammad et al. (1996). The $\mathrm{pH}$ determines not only the speciation of metal ions, but also affects the surface charge of the solid adsorbents. Rapid increase in adsorption with decrease in $\mathrm{pH}$ is usually because of combined effect of variation in the surface charge and shift in ionic species in the solution (Harter et al., 2001). It can also be explained on the basis of the nature of adsorbent. The metal oxides

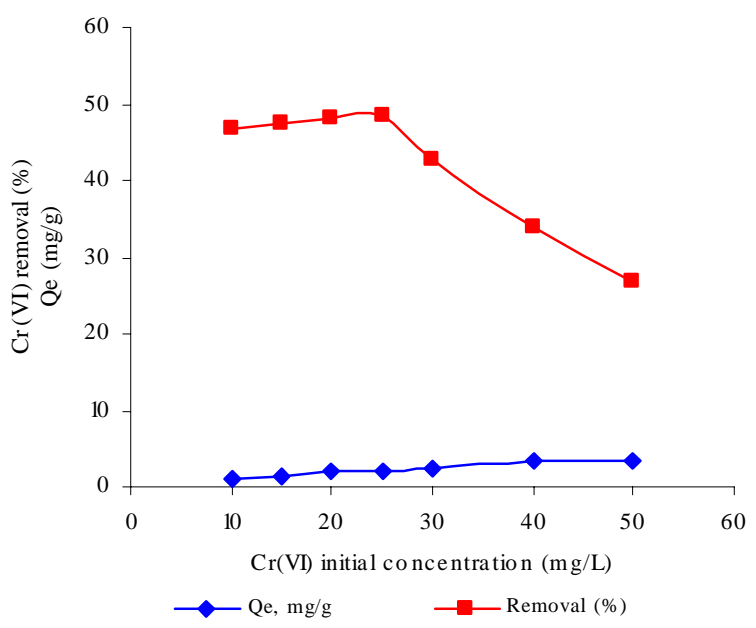

Fig. 2: Effect of initial concentration on $\mathrm{Cr}$ (VI) removal 
presents in the adsorbent undergo surface hydroxylation in aqueous solution as a result of acidbase dissociation resulting in positive or negative charged surface (Singh et al., 2005). These charges vary depending on the point of zero net charge (PZNC). The PZNC has an important impact on exchange properties of zeoliteNaX. When $\mathrm{pH}$ value is less than the PZNC, the variable charge sites develop a net positive charge and conversely, they have a net negative charge when $\mathrm{pH}$ value is greater than PZNC. Due to its anionic character, Cr (VI) is favorably adsorbed at lower $\mathrm{pH}$ values. There is equilibrium between ions like $\mathrm{H}_{2} \mathrm{CrO}_{4}$, $\mathrm{HCrO}_{4}^{-}, \mathrm{Cr}_{2} \mathrm{O}_{7}{ }^{2-}$ and $\mathrm{CrO}_{4}{ }^{2-}$ when chromium salt dissociates in aqueous solution. The equilibrium is in favor of $\mathrm{H}_{2} \mathrm{CrO}_{4}, \mathrm{HCrO}_{4}^{-}$and $\mathrm{Cr}_{2} \mathrm{O}_{7}{ }_{7}^{2-}$ ions at lower $\mathrm{pH}$ but it shifts in favor of bivalent $\mathrm{CrO}_{4}^{2-}$ ions as $\mathrm{pH}$ increases above 6.0 (Mier et al., 2001). As a result, bivalent $\mathrm{CrO}_{4}^{2-}$ ions become the dominant species. Each of these bivalent ions would neutralize twice the number of sites with univalent charge. The total adsorption capacity for $\mathrm{Cr}$ (VI) is, thus, decreased at higher $\mathrm{pH}$.

\section{Effect of initial concentration}

Equilibrium percentage removal of $\mathrm{Cr}(\mathrm{VI})$ versus initial concentration for contact time of $24 \mathrm{~h}$ is shown in Fig. 2. It was found that the percentage removal first increases up to initial concentration of $25 \mathrm{mg} / \mathrm{L}$ and then decreases with increase in initial concentration of the adsorbate. But the uptake capacity increases with increase in initial concentration, which may be due to the availability of more number of $\mathrm{Cr}$ (VI) ions in solution for adsorption. Moreover, higher initial adsorbate concentration provided higher driving force to overcome various mass transfer resistances of the metal ions from the aqueous to the solid phase resulting in higher probability of collision between $\mathrm{Cr}$ (VI) ions and the active sites. This also resulted in higher uptake of $\mathrm{Cr}$ (VI) for the given amount of zeoliteNaX.

\section{Effect of contact time}

The amount of metal adsorbed also depends on contact time if other parameters like initial concentration, temperature, $\mathrm{pH}$, etc. are kept constant. The effect of contact time on percentage removal of $\mathrm{Cr}$ (VI) at optimum pH of 4.0 and temperature of $293 \pm 1 \mathrm{~K}$ is shown in Fig. 3. It shows that $\mathrm{Cr}(\mathrm{VI})$ removal increases with increasing contact time at all the initial concentrations and temperatures and approximately $40-50 \%$ of maximum $\mathrm{Cr}$ (VI) removed is attained within $10-25 \mathrm{~min}$ and themaximum adsorption is attained in about 45 to $60 \mathrm{~min}$. No further increase in adsorption was noticed up to $24 \mathrm{~h}$. The initial rapid rate of adsorption may be due to the availability of the positively charged surface of the adsorbent for anionic $\mathrm{Cr}$ (VI) species present in the solution. The later slow adsorption rate part of the curve may be due to the electrostatic hindrance caused by already adsorbed negatively charged adsorbate species and the slow pore diffusion of the ions (Ghosh and Goswami, 2005).

\section{Effect of temperature}

Temperature has an important effect on the process of adsorption. The percentage of $\mathrm{Cr}$ (VI) adsorption is studied as a function of temperature. The results obtained are presented in Fig. 3 at temperatures of $293 \mathrm{~K}$ and 303 $\mathrm{K}$. The decrease in percentage of adsorption with rise in temperature may be due to desorption caused by an increase in the available thermal energy. Higher temperature induces higher mobility of the adsorbate causing desorption.

\section{Equilibrium isotherm}

The equilibrium study was carried out for the removal of Cr (VI) by zeoliteNaX. Equilibrium equation, commonly known as sorption isotherm, is basic requirement for the design of a sorption system. The isotherm provides information on the capacity of the sorbent or the amount required for removing a unit mass of pollutant under the operating conditions. Optimizing the design of sorption system to remove Cr (VI) from effluent requires appropriate correlation for the equilibrium data. Four isotherms, namely, Langmuir, Freundlich, Temkin and Redlich-Peterson were tested in the present study. The Langmuir isotherm, one of the first theoretical treatments of non-linear adsorption has been successfully applied to a wide range of data that exhibit limiting or maximum adsorption capacities. It assumes uniform energies of adsorption onto the surface and no transmigration of the adsorbate in the plane of the surface. The linear form of the Langmuir isotherm is as follows:

$$
\frac{1}{Q_{e}}=\left(\frac{1}{b Q_{o}}\right) \frac{1}{C_{A e}}+\frac{1}{Q_{o}}
$$

Where, $Q e(\mathrm{mg} / \mathrm{g})$ is the adsorbate amount adsorbed on adsorbent at equilibrium and $C_{A e}(\mathrm{mg} / \mathrm{L})$ is equilibrium adsorbate concentration in solution. The parameters $Q_{\mathrm{o}}(\mathrm{mg} / \mathrm{g})$ and $b(\mathrm{~L} / \mathrm{mg})$ are the Langmuir constants that relate the maximum adsorption capacity and energy of adsorption. If the data yield a linear plot $1 / Q_{e}$ versus $1 /$ $C_{A e}$ then it conform to Langmuir isotherm. A further 


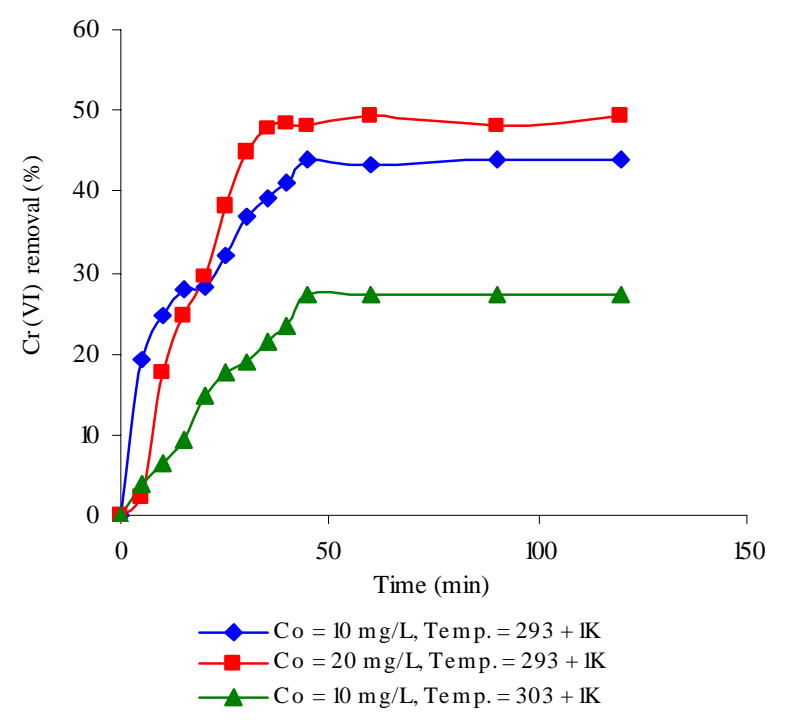

Fig. 3: Effect of contact time and temperature on Cr (VI) removal

analysis of the Langmuir equation can be made on the basis of a dimensionless equilibrium parameter $R_{\mathrm{L}}$ (Malik, 2004), known as the separation factor, as given by Eq. 4 .

$$
R_{L}=\frac{1}{1+b C_{A o}}
$$

The value of $R_{\mathrm{L}}$ provides information as to whether the adsorption is irreversible $\left(R_{\mathrm{L}}=0\right)$, favorable $(0<$ $\left.R_{\mathrm{L}}<1\right)$, linear favorable $\left(R_{\mathrm{L}}=1\right)$ or unfavorable $\left(R_{\mathrm{L}}>1\right)$.

Freundlich isotherm represents adsorption equilibrium and is widely used. The empirical equation is capable of describing the adsorption of organic and inorganic compounds on a wide variety of adsorbents. The logarithmic form of the equation is often used to fit batch equilibrium data.

$\ln Q_{e}=\ln K_{F}+\left(\frac{1}{n}\right) \ln C_{A e}$

Where, $K_{\mathrm{F}}(\mathrm{mg} / \mathrm{g})$ and $1 / n$ indicate adsorption capacity and adsorption intensity, respectively.

The linear plot of $\ln Q_{\mathrm{e}}$ versus $\ln C_{A \mathrm{e}}$ gives slope of value $1 / n$ and an intercept $\ln K_{\mathrm{F}}$. When $C_{A \mathrm{e}}$ equals unity $\ln K_{\mathrm{F}}$ is equal to $\ln Q_{\mathrm{e}}$. In the other case, when $1 / n=1$, the $K_{\mathrm{F}}$ value depends on the units in which $Q_{e}$ and $C_{A \mathrm{e}}$ are expressed. A favorable adsorption tends to give Freundlich constant $n$ a value between 1 and 10. Larger value of $n$ (smaller value of $1 / n$ ) implies strong interaction between sorbent and metal ions while $1 / n$ equal to 1 indicates linear adsorption leading to identical adsorption energies for all the sites. Freundlich equation fits in nearly all experimental adsorption desorption data and is especially useful for data from highly heterogeneous sorbent systems (Jonethan, 2009). Temkin isotherm was first proposed to predict adsorption of Hydrogen on platinum electrode in acidic solutions (Jonethan, 2009). Temkin isotherm is based on the assumption that the decline of the heat of adsorption as a function of temperature is linear rather than logarithmic, as implied in the Freundlich equation. A linear form of the Temkin equation can be expressed as:

$Q_{e}=A+B \ln C_{A e}$

Where, $A(\mathrm{mg} / \mathrm{g})=\left(R T / b_{t}\right) \ln \left(a_{t}\right)$ and $B(\mathrm{~L} / \mathrm{mg})=(R T /$ $\left.b_{t}\right)$. If a straight line is obtained when $Q_{e}$ vs. $\ln C_{A e}$ is plotted, the intercept on $Y$-axis gives value of $A$ and the slope can be used to calculate $B$. Calculated values of $A$ and $B$ are subsequently used for estimating Temkin constants $a_{t}$ and $b_{t}$ related to the maximum adsorption capacity and energy of the adsorption. RedlichPeterson isotherm (Liu and Liu, 2008) is known as three parameter isotherm which represents adsorption equilibrium over a wide concentration range and is represented by the following empirical equation:

$\ln \left(\frac{C_{A e}}{Q e}-\frac{1}{k_{r p}}\right)=\ln \frac{\alpha}{k_{r p}}+\beta \ln C_{A e}$

Eq. 7 reduces to a linear isotherm at low surface coverage and to the Langmuir isotherm when $\beta$ is equal to 1 . This model fits accurately to the data for several systems, namely bio-adsorption of chromium using suspended and immobilized cells of Rhizopus arrhizus (Preetha, 2007), adsorption of cadmium on coconut copra meal (Ho and Ofomaja, 2006), sorption of lead (II) onto peat (Ho, 2006). Redlich and Peterson isotherm incorporates the characteristics of both Langmuir and Freundlich isotherms into a single equation.

Eq. 7 indicates that plot between $\ln \left(\frac{C_{A e}}{Q e}-\frac{1}{\mathrm{k}_{\mathrm{rp}}}\right)$ and

$\ln C_{A e}$ will be a straight line with slope b and intercept $\ln \left(\mathrm{a} / \mathrm{k}_{\mathrm{rp}}\right)$ for constant $\mathrm{k}_{\mathrm{rp}}$. Hence, experimental data could be regressed for different value of $\mathrm{k}_{\mathrm{rp}}$ and optimum value of $\mathrm{k}_{\mathrm{rp}}$ may be selected for maximum regression coefficient and hence the magnitude of $\alpha$ can be evaluated. The constants evaluated for Langmuir (Eq. (3)), Freundlich (Eq. (5)), Temkin (Eq. 


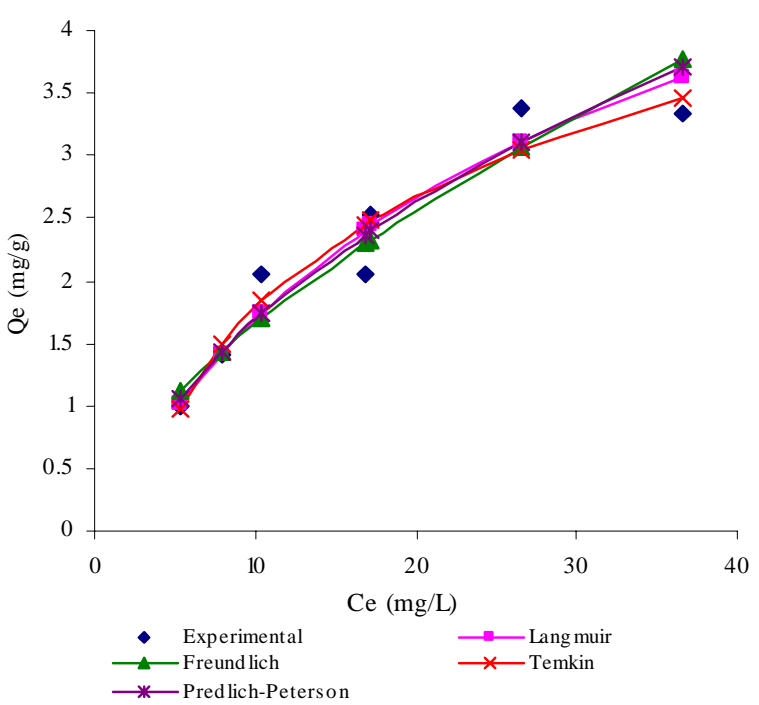

Fig. 4: Asdorption isotherm at Temp. 293+1K, pH 4.0

Table 1: Estimated isotherm parameters for $\mathrm{Cr}$ (VI) adsorption at $293 \pm 1 \mathrm{~K}, \mathrm{pH} 4.0$.

\begin{tabular}{lcl}
\hline Isotherms & $\mathrm{R}^{2}$ & Estimated isotherms parameters \\
\hline Langmuir & 0.9711 & $Q_{o}=6.414 \mathrm{mg} / \mathrm{g}, \mathrm{b}=0.0357 \mathrm{~L} / \mathrm{mg}$ \\
Freundlich & 0.9232 & $K_{\mathrm{F}}=0.3866, n=1.583$ \\
Temkin & 0.9281 & $\mathrm{a}_{\mathrm{t}}=0.403, \mathrm{~b}_{\mathrm{t}}=0.00053$ \\
Redlich-Peterson & 0.8057 & $\mathrm{Kr}=0.3008, \alpha=0.152, \beta=0.7121$ \\
\hline
\end{tabular}

(6)) and Redlich-Peterson (EQ. (7)) isotherms by regressing the experimental data are presented in Table 1. The experimental and predicted results for zeoliteNaX at $293 \pm 1 \mathrm{~K}$ are shown in Fig. 4. The regression coefficient $\left(\mathrm{R}^{2}\right)$ for Langmuir, Freundlich, Temkin and Redlich-Peterson isotherms are found to be $0.9711,0.9232,0.9281$ and 0.8057 , respectively. Thus, the Langmuir adsorption isotherm is the best model for $\mathrm{Cr}$ (VI) adsorption on to zeoliteNaX. In the Langmuir equation, $\mathrm{Q}_{0}(\mathrm{mg} / \mathrm{g})$ is the measure of adsorption capacity under the experimental condition and the value is $6.414 \mathrm{mg} / \mathrm{g}$ and the other constant $\mathrm{b}$ is used to evaluate dimensionless constant called separation factor or equilibrium parameter $\left(\mathrm{R}_{\mathrm{L}}\right)$ using Eq. 3. The calculated values of $\mathrm{R}_{\mathrm{L}}$ for the initial Cr (VI) concentration of 10, 20 and $30 \mathrm{mg} / \mathrm{L}$ are $0.7369,0.5834$ and 0.4828 , respectively. This reflects that in all the cases, $\mathrm{R}_{\mathrm{L}}$ values fall between 0 and 1 , indicating favorable adsorption of $\mathrm{Cr}(\mathrm{VI})$ on zeoliteNaX.

\section{Adsorption kinetics \\ Equilibrium study is important in determining the}

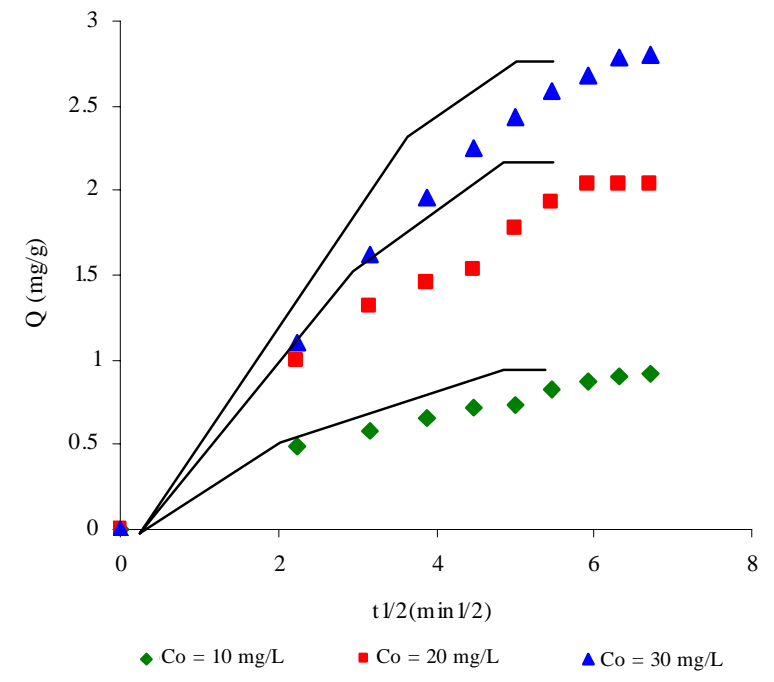

Fig. 5: Intraparticle diffusion of $\mathrm{Cr}(\mathrm{VI})$ on ZeoliteNaX at $\mathrm{pH}$ 4.0, Temp. $293+1 \mathrm{~K}$

efficacy of adsorption. It is also necessary to identify the adsorption mechanism for a given system. Kinetic models have been exploited to test the experimental data and to find the mechanism of adsorption and its potential rate-controlling step that include mass transport and chemical reaction. In addition, information on the kinetics of metal uptake is required to select the optimum conditions for full scale batch or continuous metal removal processes. Adsorption kinetics is expressed as the solute removal rate that controls the residence time of the sorbate in the solid-solution interface. Several kinetic models are used to explain the mechanism of adsorption processes. These models include Pseudo-first-order rate model and Pseudo-secondorder rate model (Rangaraj, 2003), First-order reversible reaction model (Ghosh and Goswami, 2005), Elovich's model (Ho and Mckey, 1998) and intraparticle diffusion model (Rangaraj, 2003). For the data obtained in the present study, first-order rate model and second-order rate model based on change in adsorbate concentration $\left(C_{A}\right)$ with time are also tested (Levenspiel, 1999).

\section{First order model}

The first order rate equation is generally expressed as:

$$
-\ln \frac{C_{A}}{C_{A o}}=k_{1} t
$$


Where, $\mathrm{k}_{1}$ is the rate constant for adsorption. Plot of $-\ln \left(C_{A} / C_{A o}\right)$ Vs $t$ would, therefore, be a straight line passing through origin and the slope will give the rate constant $\mathrm{k}_{1}$.

\section{Second order model}

The second order rate model is also based on change in adsorbate concentration with time and is generally expressed as:

$\frac{1}{C_{A}}-\frac{1}{C_{A o}}=k_{1} t$

Plot of $\left(1 / C_{A}\right)$ vs. $t$ results in a straight line and its slope gives the rate constant $\mathrm{k}_{1}$.

\section{Pseudo first order model}

The Pseudo first order rate model based on adsorption capacity of adsorbent and is generally expressed as:

$$
\ln \left(Q_{e}-Q\right)=\ln Q_{e}-k_{1} t
$$

Where, $Q_{e}$ and $Q$ are the amounts (mg/g) of Cr (VI) adsorbed at equilibrium and at time $(\mathrm{t})$, respectively. Plot of $\ln \left(Q_{e}\right.$ “ $\left.Q\right)$ versus $t$ gives a straight line for first order adsorption kinetics which allows computation of the rate constant $k_{1}$.

\section{Pseudo-second order model}

Pseudo-second order model is derived on the basis of adsorption capacity of the solid phase, expressed as:

$$
\frac{t}{Q}=\frac{t}{Q_{e}}+\frac{1}{k_{1} Q_{e}^{2}}
$$

The pseudo-second-order rate constant $k_{1}$ is determined from experimental data by plotting $t / Q$ vs. $t$.

\section{Elovich model}

Adsorption data can also be analyzed using the Elovich equation at the following linear form:

$Q=\frac{1}{\sigma} \ln (\theta \sigma)+\frac{1}{\sigma} \ln (t)$

Where, $\theta$ is the initial adsorption rate constant and the parameter $\sigma$ is related to the extent of surface coverage and activation energy for chemisorption. Plot between $\mathrm{Q}$ and $\ln (t)$ would be a straight line and slope of the line would give $(1 / \sigma)$ and the intercept on Y-axis would provide the value of $\{(1 / \sigma) \ln (\theta \sigma)\}$. Thus, parameters $\theta$ and $\sigma$ can be evaluated.

\section{First order reversible reaction model}

This model is mostly used for biosorption kinetics (Ghosh and Goswami, 2005). It can, however, describe the adsorption and desorption phenomena simultaneously using rate constant parameters. This model assumes that adsorption of metal (A) on adsorbent (B) follows first-order reversible reaction. The integral form for the model is represented by:

$-\ln \left(\frac{C_{A}-C_{A e}}{C_{A o}-C_{A e}}\right)=\left(k_{1}+k_{2}\right) t$

Where, $\mathrm{k}_{1}$ and $\mathrm{k}_{2}$ are rate constants for adsorption and desorption. The plot between $\left[-\ln \left\{\left(\mathrm{C}_{\mathrm{A}}-\mathrm{C}_{\mathrm{Ae}}\right) /\left(\mathrm{C}_{\mathrm{Ao}}-\right.\right.\right.$ $\left.\left.\mathrm{C}_{\mathrm{Ae}}\right)\right\}$ ] vs $t$ would be a straight line with slope $\left(k_{1}+k_{2}\right)$. The constants $\mathrm{k}_{1}$ and $\mathrm{k}_{2}$ are related to sorbate concentration as:

$\frac{k_{1}}{k_{2}}=\frac{X_{A e}}{1-X_{A e}}=\frac{C_{A o}-C_{A e}}{C_{A e}}$

Where, $X_{A e}$ is fraction adsorption at equilibrium. Hence, $k_{1}$ and $k_{2}$ can be computed.

Experimental data are regressed to identify the adsorption mechanism for a given system using firstorder rate model (Eq. (8)), second-order rate model (Eq. (9)), Pseudo-first-order rate model (Eq. (10)), PseudoSecond-order rate model (Eq. (11)), Elovich's model (Eq. (12)), first-order reversible reaction model (Eq. (13) and (14)). The results obtained are summarized in Table 2. Kinetics of $\mathrm{Cr}$ (VI) adsorption on zeoliteNaX is described well by $2^{\text {nd }}$ order kinetic equation at $10 \mathrm{mg} / \mathrm{L}$ $\left(\mathrm{R}^{2}=0.9537\right)$ and $20 \mathrm{mg} / \mathrm{L}\left(\mathrm{R}^{2}=0.9573\right)$, Pseudo-firstorder rate model at $10 \mathrm{mg} / \mathrm{L}$ and $30 \mathrm{mg} / \mathrm{L}\left(\mathrm{R}^{2}=0.9571\right.$, $0.9568)$, Pseudo second order model at $30 \mathrm{mg} / \mathrm{L}\left(\mathrm{R}^{2}=\right.$ $0.9647)$ and Elovich equation at $10 \mathrm{mg} / \mathrm{L}\left(\mathrm{R}^{2}=0.9517\right)$ and $20 \mathrm{mg} / \mathrm{L}\left(\mathrm{R}^{2}=0.9833\right)$. Only the first order reversible reaction model fits well with all sorbate concentrations having regression coefficient $>0.95$. Further, it can be seen from Table 2 that the forward rate constant for the removal of chromium is much higher than the backward rate constant, namely the desorption process. The low value of $k_{2}$ (rate constant for desorption process) indicates that the adsorbed chromium is relatively 
stable on the adsorbent at temperature and concentration studied.

\section{Intraparticle diffusion model}

When mass transfer is the controlling step it is important to identify the diffusion mechanism so Intraparticle-diffusion model is also tested. According to this model, initial rate of the intraparticle-diffusion is given by the following equation (Sengil, 2009).

$Q=k_{\text {int }} t^{1 / 2}$

Where, $k_{\text {int }}\left(\mathrm{mg} / \mathrm{g}-\mathrm{min}^{1 / 2}\right)$ is the intraparticle-diffusion rate constant and $Q$ is the amount of ions adsorbed (mg/g) at time $t(\mathrm{~min})$. Plot of $q$ versus $t^{1 / 2}$ is shown in Fig. 5 for different initial concentrations. All the curves have the same general features. The initial steep portion is followed by gradual linear portion representing the intraparticle diffusion and the plateau represents the equilibrium. Intraparticle diffusion rate constant, $k_{\text {int }}$ values are calculated from the slope of gradual linear portion of the curves for $\mathrm{C}_{\mathrm{A} 0}$ of 10,20 , and 30 are found to be $0.0863\left(\mathrm{R}^{2}=0.9613\right), 0.5397\left(\mathrm{R}^{2}=0.9787\right)$ and 0.5795 $\left(\mathrm{R}^{2}=0.9697\right)$, respectively. The value for $k_{\text {int }}$ is higher at higher concentration.

\section{Thermodynamic parameters}

Thermodynamic parameters are required to predict the nature of adsorption of $\mathrm{Cr}$ (VI) on zeoliteNaX. Gibbs free energy (" $\mathrm{G}^{\circ}$ ), enthalpy change (" $\mathrm{H}^{\circ}$ ) and entropy change (" $\mathrm{S}^{\circ}$ ) are some of the important thermodynamic parameters that need to be calculated. The thermodynamic constants; enthalpy change (" $\mathrm{H}^{\circ}$ ) and entropy change (" $\mathrm{S}$ ) are calculated using the following Eqs. 16 and 17.

$\ln K=\frac{\Delta H^{o}}{R} \frac{1}{T}+\frac{\Delta S^{o}}{R}$

Plot of $\operatorname{lnK}$ vs $1 / T$ is used to find the values of " $\mathrm{H}^{\circ}$ and " $\mathrm{S}$ " from the slope and the intercept. The free energy, " $\mathrm{G}^{\circ}$ for the specific adsorption is calculated using:

$\Delta G^{o}=\Delta H^{o}-T \Delta S^{o}$

Where, $\mathrm{K}$ is equilibrium constant, $\mathrm{R}$ is ideal gas constant ( $8.314 \mathrm{~J} / \mathrm{mol} \mathrm{K}$ ), " $\mathrm{G}^{\circ}$ and " $\mathrm{H}^{\circ}$ are in $\mathrm{J} / \mathrm{mol}$, " $\mathrm{S}$ ' is in $\mathrm{J} / \mathrm{mol} \mathrm{K}$. The calculated thermodynamic parameters are shown in Table 3. The negative value of heat of reaction " $H^{\circ}$ indicates that sorption of $\mathrm{Cr}(\mathrm{VI})$ on zeoliteNaX is exothermic. The value of " $\mathrm{G}^{\circ}$ for adsorption changes from negative to positive with increasing temperature, that means sorption is less favoured at high temperatures. The decrease in entropy, " $\mathrm{S}$ shows that the sorbate ions are stable on the solid surface. Association, fixation or immobilization of $\mathrm{Cr}(\mathrm{VI})$ ions as a result of adsorption

Table 2: Kinetic models and other statistical parameters at $293 \pm 1 \mathrm{~K}$ and at $\mathrm{pH} 4.0$

\begin{tabular}{|c|c|c|c|c|c|}
\hline \multirow{2}{*}{ Kinetic model } & \multirow{2}{*}{ Parameters } & \multicolumn{3}{|c|}{ Initial Cr (VI) concentration } & \multirow[b]{2}{*}{ Mean } \\
\hline & & $10 \mathrm{mg} / \mathrm{L}$ & $20 \mathrm{mg} / \mathrm{L}$ & $30 \mathrm{mg} / \mathrm{L}$ & \\
\hline \multirow[t]{2}{*}{ First-order equation } & $\mathrm{R}^{2}$ & 0.7669 & 0.9454 & 0.8269 & \\
\hline & $\mathrm{k}_{1}\left(\min ^{-1}\right)$ & 0.0145 & 0.0171 & 0.0149 & 0.0155 \\
\hline \multirow[t]{2}{*}{ Second-order equation } & $\mathrm{R}^{2}$ & 0.9537 & 0.9573 & 0.9451 & \\
\hline & $\mathrm{k}_{1}(\mathrm{~g} / \mathrm{mg}) / \mathrm{min}$ & 0.0015 & 0.0012 & 0.0005 & 0.0010 \\
\hline \multirow{2}{*}{ Pseudo-first-order rate } & $\mathrm{R}^{2}$ & 0.9571 & 0.7746 & 0.9414 & \\
\hline & $\mathrm{k}_{1}\left(\min ^{-1}\right)$ & 0.0676 & 0.1408 & 0.0926 & 0.1003 \\
\hline \multirow[t]{2}{*}{ Pseudo-second-order } & $\mathrm{R}^{2}$ & 0.8641 & 0.3685 & 0.7354 & \\
\hline & $\mathrm{k}_{1}(\mathrm{~g} / \mathrm{mg}) / \mathrm{min}$ & 0.2245 & 2.9282 & 0.3038 & 1.152 \\
\hline \multirow[t]{3}{*}{ First-order reversible reaction } & $\mathrm{R}^{2}$ & 0.9601 & 0.9736 & 0.9848 & \\
\hline & $\mathrm{k}_{1}\left(\min ^{-1}\right)$ & 0.0557 & 0.0196 & 0.0594 & 0.045 \\
\hline & $\mathrm{k}_{2}\left(\min ^{-1}\right)$ & 0.0074 & 0.0014 & 0.0202 & 0.0096 \\
\hline \multirow[t]{3}{*}{ Simple Elovich equation } & $\mathrm{R}^{2}$ & 0.9517 & 0.9833 & 0.9358 & \\
\hline & $\theta$ & 0.3021 & 0.2147 & 0.4872 & 0.3347 \\
\hline & $\sigma$ & 4.5086 & 1.0734 & 1.0948 & 2.2256 \\
\hline
\end{tabular}

Table 3: Calculated k1, k2 and thermodynamic parameters for $\mathrm{Cr}$ (VI) adsorption at $\mathrm{pH} 4.0, \mathrm{Co}=10 \mathrm{mg} / \mathrm{L}$

\begin{tabular}{lccccc}
\hline $\begin{array}{l}\text { Temperature } \\
\left({ }^{0} \mathrm{~K}\right),\end{array}$ & $X_{A e}$ & $\begin{array}{c}\mathrm{k}_{1} \\
\left(\mathrm{~min}^{-1}\right)\end{array}$ & $\begin{array}{c}\mathrm{k}_{2} \\
\left(\mathrm{~min}^{-1}\right)\end{array}$ & $\begin{array}{c}\Delta \mathrm{G}^{0} \\
(\mathrm{KJ} / \mathrm{mole})\end{array}$ & $\begin{array}{c}\Delta \mathrm{H}^{0} \\
(\mathrm{KJ} / \mathrm{mole})\end{array}$ \\
\hline 293 & 0.883 & 0.0557 & 0.0074 & -4.76045 & -148.322 \\
303 & 0.433 & 0.0150 & 0.0196 & 0.13657 & -0.4892 \\
308 & 0.297 & 0.0139 & 0.0329 & 2.58509 & \\
\hline
\end{tabular}


Table 4: Equilibrium adsorption capacity at $\mathrm{pH}$ 4.0, Temp. $303 \pm 1 \mathrm{~K}$

\begin{tabular}{lcc}
\hline $\begin{array}{l}\text { Regeneration } \\
\text { No. }\end{array}$ & $\begin{array}{c}\text { Initial Cr (VI) } \\
\text { Concentration } \\
\text { (mg/L) }\end{array}$ & $\begin{array}{c}\text { Equilibrium Cr (VI) } \\
\text { removal (\%) }\end{array}$ \\
\hline I & 10 & 44.40 \\
II & 10 & 42.71 \\
III & 10 & 42.79 \\
\hline
\end{tabular}

is attributed to a decrease in the degree of freedom of adsorbate ions which gives rise to a negative entropy change. Decrease in value of equilibrium constant with temperature rise signifies that the sorption of $\mathrm{Cr}(\mathrm{VI})$ onto zeoliteNaX is exothermic in nature. Since adsorption process is exothermic as a rule, the rate constant value of $\mathrm{k}_{1}$ should decrease with increasing temperature. If the adsorption is exothermic, desorption would be endothermic according to Le Chatelier's principle. Therefore, value of $\mathrm{k}_{2}$ should increase when temperature rises.

\section{Regeneration study}

The Zeolite was regenerated thrice and used to find equilibrium adsorption of $\mathrm{Cr}(\mathrm{VI})$ for a contact time of $24 \mathrm{~h}$ at initial concentration of $10 \mathrm{mg} / \mathrm{L}$, $\mathrm{pH}$ of 4.0 and temperature $303 \mathrm{~K}$. The results of the regeneration study are shown in Table 4. The results show that the adsorption capacity did not decrease appreciably. Hence, zeolitesNaX could be used several times for removal of $\mathrm{Cr}$ (VI). Zeolite are being used in pressure swing adsorbers (PSA) for a long time and it is well established that recharge/replacement of zeolites is carried out after thousands of cylcles. The zeolite materials are frequently used as a base for catalysts in several applications (Srivastava, et al., 2005).

\section{CONCLUSION}

ZeoliteNaX is identified as an efficient adsorbent for use in the treatment of water contaminated with hexavalent chromium. The results show that zeoliteNaX can efficiently remove chromium from solutions especially at $\mathrm{pH}$ close to 4.0 down to $\mathrm{ppm}$ level. The Langmuir isotherm gives the best fit for the equilibrium data of $\mathrm{Cr}$ (VI) adsoption. Chromium adsorption on zeoliteNaX follows first-order reversible kinetics. The low value of specific rate constant for reverse reaction (desorption process) indicates that the adsorbed chromium is relatively stable on the adsorbent. Therefore, zeoliteNaX can be used for the tertiary level treatment of potable water as well as industrial effluents for the removal of $\mathrm{Cr}(\mathrm{VI})$. The kinetics data are useful for the design and fabrication of wastewater treatment plant. Extensive studies are, however, required to evaluate zeoliteNaX in terms of its competitive adsorption properties and reaction chemistry for situations when other cations and anions are also present in the solution.

\section{ACKNOWLEDGEMENTS}

The authors gratefully acknowledge the facilities provided for research by University School of Chemical Technology, Guru Gobind Singh Indraprastha University, Delhi 110403, India.

\section{REFERENCES}

Agarwal, D.; Goyal, M.; Bansal, R. C., (1999). Adsorption of chromium by activated carbon from aqueous solution. Carbon, 37 (12), 1989-1997 (9 pages).

Bradl, H. B., (2004). Adsorption of heavy metal ions on soils and soils constituents. J. Colloid Interf. Sci., 277 (1), 1-18 (18 pages).

Curkovic, L.; Stefanovic, C.; Filipova, T., (1997). Metal ion exchange by natural and modified Zeolites. Water Res., 31 (6), 1379-1382 (4 pages).

Daneshvar, N.; Salari, D.; Aber, S., (2002). Chromium adsorption and $\mathrm{Cr}$ (VI) reduction to trivalent $\mathrm{Cr}$ in aqueous solution by soya cake. J. Hazard. Mater., 94 (1), 49-61 (13 pages).

Fendrof, S. E.; Sparks, D. L.; Lamble, G. M.; Kelly, M. J., (1994). Applications of X-ray Absorption Fine Structure Spectroscopy to Soils. Soil Sci. Soc. Am. J., 58, 1583-1595 (13 pages).

Ghosh, U. C.; Goswami, S., (2005). Studies on adsorption behaviour of $\mathrm{Cr}$ (VI) onto synthetic hydrous stannic oxide. Water SA., 31 (4), 597-602 (6 pages).

Guo, Y.; Qi, J.; Yang, S.; Yu, K.; Wang, Z.; Xu, H., (2003). Adsorption of $\mathrm{Cr}$ (VI) on micro and mesoporous rise husk based active carbon. Mater. Chem. Phys., 78 (1), 132-137 (6 pages).

Gupta, S.; Babu, B. V., (2006). Adsorption of chromium (VI) by a low cost adsorbent prepared from Tamarind Seeds. CHEMCON-2006, Dec27-30, India.

Hamadi, N. K.; Chen, D.; Farid, M. M.; Lu M. G. Q., (2001). Adsorption kinetics for removal of $\mathrm{Cr}$ (VI) from aqueous solution by adsorbents derived from used tyres and sawdust. Chem. Eng. J., 84 (2), 95-105 (11 pages).

Harter, R.; Naidu, R., (2001). An assessment of environmental and solution parameter impact on trace-metal sorption by soils. Soil Sci. Soc. Am. J., 65, 597-612 (15 pages).

Ho, Y.; Ofomaja, A. E., (2006). Biosorption thermodynamics of cadmium on coconut copra meal as biosorbent. Biochem. Eng. J., 30 (2), 117-123 (6 pages).

Ho, Y., (2006). Isotherms for the sorption of lead onto peat: comparison of linear and non-linearmethods. Polish J. Environ. Stud., 15 (1), 81-86 (6 pages).

Ho, Y. S.; McKay, G., (1998). A comparison of chemisorption kinetic models applied to pollutant removal on various sorbents. Process Saf. Environ., 332-340 (9 pages).

Inglezakis, V. J.; Moizidou, M. M.; Grigoropoulou, H. P., (2004). Ion exchange studies on natural and modified zeolites and 
the concept of exchange site accessibility. J. Colloid Interf. Sci., 275 (2), 570-576 (7 pages).

Jonethan, F.; Kosasih, A. N.; Sunarso, J.; Jua, Yi-Hsu; Indraswati, N.; Ismadji, S., (2009). Equilibrium and kinetic studies in adsorption of heavy metals using biosorbent: A summary of recent studies. J. Hazard. Mater., 162 (2-3), 616-645 (29 pages).

Khan, S. A.; Rehman, Riaz-ur; Khan, M. A., (1995). Adsorption of chromium (III), chromium (VI) and silver (I) on bentonite. Waste Manage., 15 (4), 271-282 (11 pages).

Kobya, M., (2004). Removal of Cr(VI) from aqueous solutions by adsorption onto hazelnut shell activated carbon: Kinetic and equilibrium studies. Bioresour. Tech., 91 (3), 317-321 (4 pages).

Krishna, B. S.; Murty, D. S. R.; Jai Prakash, B. B., (2000). Thermodynamics of chromium (VI) anionic species sorption onto surfactant-modified montmorillonite clay. J. Coll. Inter. Sci., 229 (1), 230-236 (7 pages).

Levenspiel O. (1999). Chemical Reaction Engineering, $2^{\text {nd. }}$ Ed. Wiley Eastern Ltd, 41-92.

Liu, Y.; Liu, Y. J., (2008). Biosorption isotherms, kinetics and thermodynamics. Sep. Purif. Tech., 61 (3), 229-242 (13 pages).

Malik, P. K., (2004). Dye removal from wastewater using activated carbon developed from sawdust: Adsorption equilibrium and kinetics. J. Hazard. Mater., 113 (1-3), 8188 (8 pages).

Mark, A. K., (1998). The removal of copper and nickel from aqueous solution using zeolite-Y ion exchanger. Colloid. Surfac. A, 138 (1), 11-20 (10 pages).

Meng, X.; Dermatas, D., (2003). Utilization of fly ash for stabilization/solidification of heavy metal contaminated soils. Eng. Geol., 70 (3-4), 377-394 (18 pages).

Meshko, D. V.; Markovska, T. L.; Mirko, S. M., (2006). Modeling of the adsorption kinetics of zinc onto granular activated carbon and natural zeolite. J. Serb. Chem. Soc., 71 (8-9), 957-967 (11 pages).

Mier, M. V.; Callejas, R. L.; Gehr, R.; Cisneros, B. E. J.; Alvarez, P. J. J., (2001). Heavy metal removal with Mexican clinoptilolite-multi component ionic exchange. Water Res., 35 (2), 373-378 (6 pages).

Mohammad., A.; Rafaqat, A. K. R.; Siddiqu, B. A., (1996). Studies on removal and recovery of $\mathrm{Cr}$ (V1) from electroplating waste. Water Res., 30 (6), 1478-1482 (5 pages).
Nameni, M.; Alavi Moghadam, M. R.; Arami, M., (2008). Adsorption of hexavalent chromium from aqueous solutions by wheat bran. Int. J. Environ. Sci. Tech., 5 (2), 161-168 (8 pages).

Okada, K.; Nishimuta, K.; Kameshima, Y.; Nakajima, A., (2005). Effect on uptake of heavy metal ions by phosphate grafting of allophane. J. Coll. Inter. Sci., 286 (2), 447-454 (8 pages).

Preetha, B.; Viruthagiri, T., (2007). Batch and continuous biosorption of chromium(VI) by Rhizopus arrhizus. Sep. Purif. Tech., 57 (1), 126-133 (8 pages).

Rengaraj, S.; Joo, C. K.; Kim, Y.; Yi, J., (2003). Kinetics of removal of chromium from water and electronic process wastewater by ion exchange resins. J. Hazard. Mater., 102 (2-3), 257-275 (19 pages).

Sengil, I. A.; Ozacar, M., (2009). Competitive biosorption of Pb2+, $\mathrm{Cu} 2+$ and $\mathrm{Zn} 2+$ ions from aqueous solutions onto valonia tannin resin. J. Hazard. Mater., 166 (2-3), 1488-1494 (7 pages).

Shah, B. A.; Shah, A. V.; Singh R. R., (2009). Sorption isotherms and kinetics of chromium uptake from wastewater using natural sorbent material. Int. J. Environ. Sci. Tech., 6 (1), 77-90 (14 pages)

Singh, K. K.; Rastogi, R.; Hasan, S. H., (2005). Removal of Cr (VI) from wastewater using rice bran. J. Coll. Inter. Sci., 290 (1), 61-68 (8 pages).

Srivastava, R. D.; Srinivas, D.; Ratnaswamy, P., (2005). Zeolitebased organic-inorganic hybrid catalysts for phosgene-free and solvent-free synthesis of cyclic carbonate and carbamates at mild conditions utilizing $\mathrm{CO}_{2}$, Appl. Catal. AGen., 289 (2) 128-134 (7 pages).

Stewart, M.; Jardine, P.; Barnett, M.; Mehlhorn, T.; Hyder, L.; McKay, L., (2003). Influence of soil geochemical and physical properties on the sorption and bioaccessibiltiy of Chromium (III). J. Environ. Quality, 32, 129-137 (9 pages).

Sun, J. M.; Li, R.; Huang, J. C., (2007). Optimum pHs for $\mathrm{Cr}(\mathrm{VI})$ co-removal with nucleated $\mathrm{Cu}(\mathrm{II})$ precipitation in continuous flow fluidized metal strippers. Water SA., 33 (1), 137-142 (6 pages).

Xie, B.; Kang, K. S., (2003). Uptake of copper ion by activated sludge and its bacterial community variation analyzed by 16S rDNA. J. Environ. Sci., 15 (3), 328-333 (6 pages).

Zvinowanda, C. M.; Okonkwo, J. O.; Shabalala, P. N.; Agyei, N. M., (2009). A novel adsorbent for heavy metal remediation in aqueous environments. Int. J. Environ. Sci. Tech., 6 (4), 425-434 (10 pages).

\section{AUTHOR (S) BIOSKETCHES}

Pandey, P. K., Ph.D., Research scholar, University School of Chemical Technology, Guru Gobind Singh Indraprashtha University, Delhi110403, India. Email: chilkahar@indiatimes.com

Sharma, S. K., Ph.D., University School of Chemical Technology, Guru Gobind Singh Indraprashtha University, Delhi-110403, India. Email: skschem@sify.com

Sambi, S. S., Ph.D., University School of Chemical Technology, Guru Gobind Singh Indraprashtha University, Delhi-110403, India. Email: sambi1950@yahoo.co.in 